\title{
Perkembangan dan Permasalahan Teorisasi Hubungan Internasional Pasca Perdebatan”
}

\author{
Dodi Mantra \\ Jurusan Hubungan Internasional, Universitas Paramadina \\ Jl. Jenderal Gatot Subroto, Mampang, Jakarta 12790 \\ mantraisme@yahoo.co.id \\ Submitted: 09 July 2015, Accepted: 15 September 2015
}

\begin{abstract}
There are two contradictory narratives those enframe the contemporary development of International Relations (IR) theory. As the absence and discontinuity of the so-called "inter-paradigm debates", the first narrative enframes the contemporary development of IR theory is moving toward its end. On the contrary, the other narrative celebrates the plurality of theoretical development in contemporary IR, and letting "a thousand theoretical flowers bloom". This article seeks to reveal that both of these narratives are problematic. The main problem of the first narrative lies in the "debatism" approach as the basis of its historiography. This article shows how the "debatism" approach misrepresents the history of IR theorization. Meanwhile, the second narrative is problematic as well, since the celebration of theoretical plurality tends to neglect the philosophical foundations and concentrate on the technical side of theorization. Drawing on Fred Chernoff's steps of IR theorization, this article proposes a new frame of IR theorization in order to leave behind the problematic "debatism" approach, while proliferate "a thousand of theoretical flowers bloom" without neglecting the importance of philosophical foundations in IR theorization.
\end{abstract}

Key words: international relations debates, plularity, theorization, contruction

\begin{abstract}
Abstrak
Ada dua narasi kontradiktif yang membingkai perkembangan teori Hubungan Internasional. Di satu sisi muncul semacam kerisauan akan berakhirnya teori HI seiring dengan semakin absennya perdebatan yang mewarnai perkembangan studi ini. Sementara itu, pada sisi lain, terdapat narasi yang justru merayakan optimisme akan berseminya bunga-bunga teori sebagai tanda yang cerah bagi masa depan perkembangan studi hubungan internasional. Problem dari gejala pertama adalah munculnya semacam "debatisme" yang melahirkan kesalahan persepsi atas sejarah perkembangan teori hubungan internasional. Sedang fenomena kedua mengidap problem berupa miskinnya debat-debat filosofis dan mendasar yang amat diperlukan dalam memperkaya perspektif hubungan internasional. Tulisan ini bertujuan untuk membingkai dua kecenderungan tersebut untuk kemudian melihat ruangruang baru eksplorasi teoritis yang penting dalam perkembangan studi Hubungan Internasional.
\end{abstract}

Kata kunci: debat studi hubungan internasional, keragaman, teorisasi, kontruksi

\section{PENDAHULUAN}

Dua bentuk narasi utama tampak membingkai kisah dan perbincangan mengenai perkembangan teori Hubungan Internasional (HI) terkini. Di satu sisi muncul kisah kegelisahan akan berakhirnya teori $\mathrm{HI}$ seiring dengan semakin sunyinya perdebatan yang mewarnai perkembangan studi ini. Sementara itu, di tengah-tengah duka akan "matinya teori HI," muncul kisah lain yang justru merayakan kebahagiaan akan berseminya bunga-bunga teori sebagai tanda yang cerah bagi masa depan perkembangan studi Hubungan
Internasional.

Artikel ini berupaya untuk membongkar permasalahan yang terkandung di dalam dua bentuk narasi yang mengisahkan tentang kondisi dan arah dari perkembangan teori HI kontemporer tersebut. Dengan mempermasalahkan narasi "perdebatan" sebagai corak dominan historiografi teorisasi $\mathrm{HI}$, dan memeta ragam cerita alternatif atas sejarah perkembangan teori HI, analisis dalam artikel ini berupaya untuk menunjukkan betapa lemahnya landasan dan argumentasi dari narasi 
yang mengisahkan tentang kematian teori $\mathrm{HI}$ yang telah menebar kegelisahan bagi sebagian besar penstudinya. Dengan merujuk kembali kepada arti penting kesadaran atas filsafat ilmu (philosophy of science), artikel ini berupaya untuk mengidentifikasi beberapa permasalahan yang terkandung di dalam kisah yang merayakan suatu epos baru dalam perkembangan studi HI, di mana bunga-bunga teori kian bersemi.

Mendorong pluralisme dan membangkitkan kesadaran atas fondasi filosofis adalah tawaran utama yang diajukan dalam artikel ini sebagai pijakan bagi teorisasi HI dalam menjawab corak permasalahan dunia kontemporer. Akan tetapi, yang menjadi pertaruhan dari tawaran ini bukanlah kemajuan (progress) dari studi HI sebagai sebuah disiplin yang dapat melahirkan teori-teorinya sendiri yang canggih.Bukan untuk mendorong perkembangan studi HI sehingga menjadi benar-benar sebuah bidang ilmu pengetahuan, melainkan untuk menjadikan disiplin ini sebagai sebuah disiplin yang dapat melahirkan teoriteori di mana pengetahuan tentang dunia kontemporer dihasilkan dan jawaban atas ragam permasalahan yang spesifik dengan kontemporalitas dunia itu sendiri dihadirkan. Melalui penegasan dan modifikasi atas tahapan teorisasi HI Fred Chernoff, di dalam artikel ini ditawarkan sebuah bingkai teorisasi HI kontemporer yang berpijak pada permasalahan, kesadaran atas fondasi filosofis, pluralisme dan kompleksitas.

Pada bagian pertama dari artikel ini diuraikan beberapa konteks yang membingkai kisah tentang berakhirnya teori HI, sekaligus memperlihatkan bagaimana kisah ini sangat dipengaruhi oleh historiografi mainstream ala "perdebatan.” Dalam bagian ini juga akan dijelaskan beberapa bentuk narasi alternatif atas teorisasi HI yang memperlihatkan celah dan permasalahan dari narasi "perdebatan" yang selama ini memenjarakan perbincangan mengenai teori $\mathrm{HI}$. Bagian kedua menyasar permasalahan dalam geliat proliferasi teori-teori HI selama beberapa dekade terakhir, terutama yang dibingkai dalam kategori teoriteori penyelesaian masalah (problem-solving) yang berada pada tingkat menengah (middle-level theory). Pada bagian ketiga,akan dielaborasi tawaran atas pijakan dalam teorisasi HI kontemporer, yang mengangkat sebuah bentuk pertaruhan utama sebagai pembingkainya.

\section{PEMBAHASAN}

MATINYA TEORI HI?

"The end of International Relations theory?" adalah narasi yang membingkai perbincangan akademis mengenai status dari perkembangan teori $\mathrm{HI}$ kontemporer.Dimanifestasikan sebagai sebuah isu utama dalam European Journal of International Relations19(3) 2013, tampak narasi tentang berakhirnya teori HI menjadi perhatian utama dalam perbincangan akademisi HI hari ini (Dunne, 2013). Terdapat tiga isu yang berbeda, yang melingkari munculnya narasi tentang akhir dari teori HI ini (Nexon, 2013). Pertama, semakin memudarnya geliat "perang paradigma" sejak tahun 1990an dan awal 2000an. Kedua, semakin tidak memadainya bingkai "perdebatan besar" (Great Debates) dalam mewadahi porsi perhatian dan perkembangan teori tertentu di dalam studi HI. Ketiga, geliat proliferasi teori-teori HI, terutama yang berada dalam lingkup middle-range theory.

Benarkah ketiga bentuk dinamika ini telah membawa teorisasi HI kepada penghujung hayatnya? Haruskah kita (sebagai penstudi HI) berduka dengan munculnya obituary ini?

Berita ini menjadi duka yang sangat mendalam terutama bagi para penstudi HI yang terjebak dan meyakini serta memosisikan diri dan kerja intelektual mereka di dalam penjara historiografi mainstream atas perkembangan teori HI, baik dalam bentuk perdebatan paradigma atau "isme" maupun dalam bingkai perdebatan besar. Sehingga, jika dibingkai dalam kerangka perdebatan, adalah benar teori HI telah mati, ketika paradigma tidak lagi menjadi pijakan analisis bagi penstudinya dalam menjelaskan berbagai fenomena HI. Ketika perdebatan besar yang dijadikan sebagai ukuran dinamika, kemajuan ilmu dan inovasi teoritis telah semakin memudar, maka tanda-tanda suram akan masa depan teorisasi muncul dalam kegelisahan mereka yang terjebak dalam narasi ini. 
Survey "Teaching, Research, and Policy Views of International Relations Faculty" (TRIP) menunjukkan bahwa 22 persen dari penstudi HI sudah tidak menggunakan analisis paradigmatik di dalam kerja akademis mereka (Daniel Maliniak, 2007). Berdasarkan survey tersebut, dapat diamati bahwa semakin sedikit juga jumlah dari penstudi HI yang mengidentifikasikan diri mereka ke dalam kategori paradigma tertentu. Sebesar 22 persen penstudi HI yang menjadi responden mengidentifikasikan diri sebagai konstruktivis, 16 persen realis, dan 15 persen sebagai liberal (Daniel Maliniak, 2007). Bahkan hanya sebesar 5 persen dari penstudi HI yang di-survey yang menyatakan bahwa penelitian yang mereka dijalankan dimotivasi oleh pertimbangan paradigmatis. Sementara itu, area isu (sebesar 39 persen) dan peristiwa terkini/relevansi kebijakan (33 persen) tampak menjadi pendorong utama dari kerja akademis sebagian besar penstudi HI hari ini (Daniel Maliniak, 2007). Sehingga, jika teori HI yang dikatakan telah mati tersebut adalah kecenderungan semakin tersingkirnya posisi sentral paradigma baik bagi identitas ataupun kerja akademis penstudi HI, maka hasil survey ini menjadi penegas bagi kondisi tersebut.

Dengan kata lain, kisah tentang kematian teori HI ini adalah sebuah kisah yang muncul dari belenggu historiografi "perdebatan" yang menisbatkan kemajuan dan perkembangan teori HI selama ini hanya berjalan dalam bentuk keberadaan landasan paradigmatis dan dialog dalam bentuk perdebatan.Sebagai imbasnya, ketika dua bingkai dari geliat positif perkembangan teori HI semakin memudar dan hilang, masa depan teorisasi HI pun dipandang menjadi semakin suram. Sementara itu, beberapa refleksi kritis dan analisis meta-teoritis terhadap perkembangan teori Hlyang muncul, justru sebagian besar memperlihatkan bahwa historiografi mainstream ini justru sangatlah bermasalah dan tidak memadai dalam mengisahkan bagaimana trajektori dari perkembangan teori HI selama ini.

Narasi atas perkembangan teori HI dalam bingkai "perang paradigma" atau "isme" mengandung beberapa bentuk permasalahan yang sangat mendasar dan berimplikasi logis yang sangat serius bagi teorisasi itu sendiri. Secara keseluruhan, permasalahan mendasar dari penulisan sejarah ini terletak pada penyederhanaan dan kesalahpahaman terhadap gagasan Thomas Kuhn mengenai paradigma. Sebagai bagian dari upaya untuk memeta jalan menuju pengetahuan dan kemajuan ilmu pengetahuan, gagasan Kuhn tentang paradigma muncul sebagai respon atas prinsip falsifikasi Karl Popper dalam rangkaian panjang geliat filsafat ilmu untuk menjembatani ranah pikiran dan dunia nyata (mind-world) (Jackson, 2011). Sebagai bentuk kritik atas prinsip falsifikasi Popper dalam menggambarkan perkembangan dari ilmu pengetahuan, Kuhn memetakan sebuah rute yang berbeda dalam wujud "revolusi saintifik" yang tidak terlepas dari keberadaan paradigma, di mana ilmu pengetahuan bekerja melalui suatu proses di mana suatu paradigma dominan dihadapkan pada anomali, yang kemudian melahirkan paradigma alternatif untuk menjawab anomali tersebut atau paradigma alternatif tersebut mendapatkan semakin banyak penganut sehingga beralih posisi menjadi dominan (Bennett, 2013). Dikarenakan paradigma yang saling bertentangan ini tidak pernah selaras dan tidak memiliki titik temu serta mengarah kepada penyelesaian masalah yang berbeda, tidak ada suatu bentuk standar yang melampaui persetujuan (konsensus) dari anggota komunitas dalam pilihan paradigma, sehingga persoalan pilihan paradigma ini tidak dapat diselesaikan melalui logika dan pengalaman semata (Kuhn, 1962).

Bentuk kesalahan pertama dalam pengadopsian gagasan Kuhn tentang paradigma di dalam studi HI ini, beradapada keyakinan yang meletakkan berbagai "isme" di dalam HI mulai dari realisme sampai konstruktivisme, sebagai paradigma. Pada dasarnya, isme-isme tersebut tidaklah pernah merupakan paradigma (Jackson, 2013, p. 546). Kesemua "isme" yang muncul dalam studi HI tidak pernah mengandung konten yang benar-benar tidak selaras dan tidak memiliki titik temu satu sama lain, yang membedakannya satu sama lain dan membutuhkan rujukan dari kriteria eksternal dalam penilaian teori (Jackson, International theory in a post-paradigmatic 
era: From substantive wagers to scientific ontologies, 2013).Karakteristik yang membedakan suatu paradigma dalam bingkai berpikir Thomas Kuhn terletak pada kandungan elemen inti di dalamnya, yaitu elemen ontologis, linguistik, dan epistemologis, yang menghindarkan pengujian langsung dari teoriteori di dalam paradigma ini dengan elemen yang terkandung di dalam paradigma lain (Jackson, International theory in a post-paradigmatic era: From substantive wagers to scientific ontologies, 2013). Pada kenyataannya, "debat antar paradigma" yang terjadi di tahun 1980an dan 1990an di dalam studi HI berjalan dalam bingkai pengujian empiris antar paradigma, yang kemudian menjadi landasan bagi lemahnya pijakan untuk memasukkan isme-isme tersebut sebagai paradigma ala Kuhn (Jackson, International theory in a post-paradigmatic era: From substantive wagers to scientific ontologies, 2013). Pendekatan-pendekatan yang berkembang di dalam studi HI seperti 'realisme,' 'liberalisme,' dan 'konstruktivisme,' dengan demikian tidak dapat dikategorikan sebagai paradigma sebagaimana yang dimaksud oleh Thomas Kuhn (Nexon, 2009) (Wight, 1996).

Sebagai konsekuensinya, penulisan sejarah teori HI dalam kategori "isme-isme" ini menjadi sebuah bentuk cara yang buruk dalam memetakan ragam teori yang berkembang dalam studi HI (Nexon, 2013, p. 546). Dalam pola ini, spesifikasi-spesifikasi tertentu mengenai aktor, karakter dan lingkungan dari aktor, dan dampak interaksi terhadap perilaku aktor, dalam suatu bingkai paradigma yang seakan-akan benar-benar utuh, seakan-akan menjadi milik yang utuh dari suatu paradigma. Sementara, dalam kenyataannya, pola pembatasan agregasi teoritis ini sangat bermasalah, di mana tidak ada satu "isme" pun di dalam HI yang benar-benar memiliki secara utuh spesifikasi tertentu. Liberalisme tidaklah memonopoli variabel-variabel ekonomi di dalamnya, begitu juga dengan realismebukanlah pemilik tunggal bagi variabel kapabilitas militer dalam memahami politik internasional (Sterling-Folker, 2002).

Lebih jauh, permasalahan yang lebih mendasar muncul ketika penstudi HI memaknai paradigma- paradigma utama dalam studi ini sebagai kelompok teori mengenai mekanisme kausal yang seakan tertutup satu sama lain (Bennett, 2013). Pola ini terwujud dalam bentuk yang seringkali terjadi di mana para penstudi HI meletakkan temuan-temuan dalam penelitian mereka seakan sebagai satu "paradigma," yang menekankan pada satu bentuk mekanisme kausal dan menyingkirkan yang lain. Meskipun pada kenyataanya, tidak ada satupun dari penstudi ini yang benar-benar setia berpijak pada satu paradigma dalam menjelaskan politik internasional (Bennett, 2013).

Pola ini membawa konsekuensi lanjutan yang serius dalam memahami "paradigma" di dalam studi HI, di mana paradigma-paradigma yang berkembang di dalam studi ini diyakini memiliki kekuatan eksplanatoris dengan sendirinya. Maksudnya, paradigma itu sendiri menjadi landasan langsung dalam menjelaskan fenomena HI. Bukan merujuk kepada teori-teori yang mengandung penjelasan mekanisme kausalitas yang menyusun paradigma tersebut (Bennett, 2013). Meksipun pada kenyataannya, kekuatan eksplanatoris dari apa yang dikategorikan sebagai paradigma di dalam studi HI tersebut justru bertumpu pada teoriteori spesifik yang mengandung mekanisme kausalitas.

Bahkan ketika perkembangan metodologis dalam studi HI menunjukkan gejala pergeseran menuju konsepsi Imre Lakatos mengenai "research programme,"tampak juga bahwa penulisan sejarah teori berlandaskan pada kategori "isme" ini diwarnai oleh permasalahan. Lakatos mendefinisikan "research programme" sebagai sekumpulan teori dan teknik yang memiliki proposisi utama yang diproteksi oleh hipotesis-hipotesis pelengkap (Lakatos, 1970). "Research programme" bersifat progresif, terus mengalami pertumbuhan, menghasilkan fakta-fakta baru, prediksi, teknik, bahkan teori baru yang konsisten dengan elemen intinya (Brown, (2013). Sebaliknya, dalam kenyataan, tidak ada satupun teori HI yang benarbenar memenuhi kriteria Lakatos tersebut (Brown, (2013, p. 488) (Nexon, 2009).

Begitu juga permasalahan terkandung di dalam penulisan sejarah perkembangan teori HI dalam bingkai "Perdebatan Besar," yang dinilai selama ini 
sebagai kontroversi yang menjadi bahan bakar bagi kemajuan studi HI.Perdebatan besar, yang dikisahkan sebagai peperangan epik di antara para titan ini telah menentukan arah penelitian dan pengetahuan tentang HI selama ini (Lake, 2013). Yang menjadi permasalahan mendasar dari narasi "Perdebatan Besar" ini terletak pada representasi atas apa yang menjadi pertaruhan di dalamkisah setiap episode perdebatan, sehingga telah memicu munculnya interpretasi ulang atas kisah tersebut yang mengacu kepada perkembangan yang sesungguhnya terjadi di dunia nyata dan pertarungan disiplin akhir-akhir ini ${ }^{1}$.

Dalam upaya untuk melepaskan diri dari penjara narasi sejarah teori HI versi "Perdebatan Besar" ini, muncul narasi-narasi alternatif yang menuliskan kembali dalam cerita yang berbeda perkembangan teorisasi HIselama ini, situasi terkini dan peta jalan ke depan. Sebuah narasi alternatif yang berupaya untuk menceritakan ulang sejarah perkembangan teori $\mathrm{HI}$ dalam cara yang berbeda berangkat dari artikel Stefano Guzzini (Guzzini, 2013), yang memandang bahwa historiografi mainstream HI berimbas pada kegagalan dalam melihat ragam modus teorisasi di dalam studi HI.Guzzini menegaskan bahwa terdapat banyak modus teorisasi HI selain daripada isme-isme, yang pada dasarnya bukanlah tidak diketahui oleh penstudinya ataupun merupakan suatu bentuk modus yang baru (Guzzini, 2013, p. 522). Akan tetapi, keberadaan dari modus-modus ini cenderung diabaikan jika tidak langsung dipotong oleh dua bentuk posisi yang mengalienasi bahasa abstrak dunia akademis seiring dengan kungkungan praktis atas teorisasi $\mathrm{HI}$ dan profesionalisasi disiplin yang berujung pada homogenisasi penelitian (Guzzini, 2013, p. 522). Sehingga kemudian, munculnya pandangan bahwa teori HI semakin mengalami penurunan merupakan hasil dari kesalahan dalam memahami sifat dari teori, sikap yang mengabaikan ragam bentuk dalam teorisasi HI.

Berpijak pada posisi ini, Guzzini menarasikan ulang teorisasi HI dalam wujud empat modus yang utama. Pertama, teorisasi normatif (normative theorizing), yang tersusun atas pengaplikasian kriteria ilmiah moral dan filsafat politik terhadap isu-isu hubungan internasional (Guzzini, 2013, p. 533). Modus teorisasi normatif ini menurut Guzzini memiliki signifikansi yang sangat jelas di dalam analisis politik, sedari politik itu sendiri adalah tentang nilai. Sehingga permasalahan penelitian dalam studi HI perlu untuk dilandaskan pada isu-isu nilai politis atau etis (Guzzini, 2013, p. 533). Kedua, teorisasi meta-teoritis (meta-theoretical theorizing), yang menekankan dan menyediakan landasan bagi proses pembangunan teori (Guzzini, 2013, p. 533). Melalui klarifikasi atas aspek ontologi, epistemologi, dan metodologi, serta spesifikasi waktu, meta-teorisasi memainkan peranan penting dalam proses pemeriksanaan konsistensi asumsi dalam pembangunan teori. Sehingga, dapat dicermati perbenturan asumsi atau bahkan inkoherensi dalam proses formasi teori (Guzzini, 2013, p. 533). Ketiga, teorisasi konstitutif/ontologis (constitutive/ontological theorizing), yang mengandung aspek normatif dalam teorisasi, namun tidak ditujukan untuk merumuskan teori untuk kebaikan bersama maupun untuk menghubungkan penelitian dan posisi nilai. Yang menjadi sorotan utama dari modus teorisasi ini adalah memahami elemen penyusun dari apa yang disebut sebagai "internasional" termasuk mekanisme yang terkandung di dalamnya (Guzzini, 2013, p. 534). Keempat, teorisasi empiris (empirical theorizing), dalam wujud penelitian yang dijalankan secara induktif, berpijak pada ranah empiris untuk menangkap mekanisme kausalitas dan menjelaskan korelasi di dalam mekanisme tersebut. Guzzini menekankan bahwa analisis empiris dalam modus teorisasi ini dapat mengungkap relasi di antara cara kita memikirkan dunia dan dunia itu sendiri, di mana teori-teori dan konsep-konsep dasar yang kita gunakan dengan sendirinya merupakan obyek dari analisis empiris². Melalui elaborasi atas modus teorisasi yang sebenarnya selama ini berjalan di dalam studi HI, semakin tampak bahwa historiografi ala "perdebatan" bukanlah suatu bentuk narasi yang memadai dalam memahami perkembangan teorisasi HI selama ini, status perkembangan teori HI hari ini, bahkan masa depan dari teorisasi $\mathrm{HI}$. 
Ketika para pendukung narasi teorisasi HI dalam kerangka "debat isme" ataupun "perdebatan besar"gelisah akan situasi terkini dari perkembangan teori HI, beberapa penstudi yang mendorong narasi alternatif justru bersikap optimis mencermati dinamika positif perkembangan terkini teori HI. Jackson dan Nexon misalnya, alih-alih melihat kematian teori $\mathrm{HI}$, dengan mengangkat ontologi saintifik sebagai ukuran bagi perkembangan teori, justru menilai status teori HI terkini dalam keadaan yang sehat dan optimis akan perkembangannya ke depan (Jackson, International theory in a post-paradigmatic era: From substantive wagers to scientific ontologies, 2013, p. 546). Tentu saja, pandangan ini tidak akan lahir jika didasarkan pada pemahaman perkembangan teori dalam bingkai perdebatan tersebut. Keluar dari bingkai perdebatan, Jackson dan Nexon memeta perkembangan dan arah perkembangan teorisasi HI mengacu kepada bingkai ontologi saintifik (scientific ontology), sebagai sebuah katalog atau peta mengenai substansi dan proses dasar yang menyusun politik dunia ${ }^{3}$. Sebagai konsekuensinya, untuk membangun ulang peta teorisasi $\mathrm{HI}$, beberapa upaya harus dilakukan mencakup konstruksi ulang batasanbatasan perdebatan yang selama ini telah ada, memperluas cakupan ontologi saintifik ketimbang terjebak dalam "isme-isme," dan mencermati bentukbentuk ketidaksepakatan ketimbang mendeskripsikan agregasi teoritis (Jackson, 2013, pp. 552-553).

Sehingga, terciptalah sebuah narasi baru atas teorisasi HI yang tersusun atas tiga keluarga teori, yaitu: choicetheoretic, experience-near, dan social-relational, yang dikategorisasi berdasarkan dua ukuran, yaitu derajat otonomi aktor dari konteks atau lingkungannya dan derajat dari pengaruh konteks partikular di mana aktor tersebut berada (Jackson, 2013, p. 553).

Kemunculan narasi-narasi alternatif atau revisi penulisan sejarah perkembangan teori $\mathrm{HI}$ memperlihatkan permasalahan mendasar yang terkandung di balik historiografi mainstream, baik itu yang dibingkai oleh perdebatan "isme" ataupun "perdebatan besar.” Penulisan ulang sejarah perkembang teori HI dapat membongkar dengan cara

\section{Tabel 1 Empat Modus Teorisasi HI Stefano Guzzini}

\begin{tabular}{|c|c|}
\hline Modus Teorisasi & Karakteristik Teori \\
\hline $\begin{array}{l}\text { 1. Teorisasi } \\
\text { Normatif }\end{array}$ & $\begin{array}{l}\text { Penerapan kriteria ilmiah dari } \\
\text { filsafat moral dan politik terhadap } \\
\text { isu-isu hubungan internasional. }\end{array}$ \\
\hline $\begin{array}{l}\text { 2. Teorisasi Meta- } \\
\text { Teoritis }\end{array}$ & $\begin{array}{l}\text { Menyediakan pijakan yang menjadi } \\
\text { landasan bagi pembangunan teori. }\end{array}$ \\
\hline $\begin{array}{l}\text { 3. Teorisasi } \\
\text { Ontologis }\end{array}$ & $\begin{array}{l}\text { Meliputi pemahaman mendasar } \\
\text { terhadap segala yang dikategorikan } \\
\text { sebagai "internasional” (ontologis), } \\
\text { dengan segala konsepnya,seperti } \\
\text { anarki, hirarki, heternomi, } \\
\text { masyarakat dan komunitas, dan } \\
\text { seterusnya, begitu juga dengan } \\
\text { institusi-institusi fundamental dan } \\
\text { sekunder, seperti kedaulatan. }\end{array}$ \\
\hline $\begin{array}{l}\text { 4. Teorisasi } \\
\text { Empiris }\end{array}$ & $\begin{array}{l}\text { Mencakup analisis korelasional } \\
\text { skala makro yang mengarah } \\
\text { kepada pengujian hipotesis secara } \\
\text { deduktif, perbandingan skala } \\
\text { mikro, studi kasus tunggal dan } \\
\text { proses generalisasi. }\end{array}$ \\
\hline
\end{tabular}

Sumber: Disarikan dari Stefano Guzzini, "The ends of International Relations theory: Stages of reflexivity and modes of theorizing," European Journal of International Relations 19(3) (2013): 521-541.

yang berbeda tentang bagaimana sesungguhnya proses produksi dan reproduksi pengetahuan di dalam studi HI. Sebuah pembongkaran reflektif yang dilakukan oleh Guzzini atas akar spesifik dari teorisasi HI, memperlihatkan suatu kisah yang benar-benar berbeda dengan apa yang selama ini dikonsumsi dan direproduksi dalam studi HI itu sendiri. Cukup mengejutkan, analisis Guzzini mengungkap bagaimana proses penciptaan dan perkembangan studi HI berjalan dalam suatu trajektori terbalik dari disiplin ilmu pada umumnya. Sementara sebagian besar ilmu sosial lahir sebagai wadah bagi upaya sistematis untuk menghasilkan pengetahuan tentang dunia sosial, proses yang sebaliknya justru yang menandai kelahiran studi HI.

"Whereas most social sciences are born out of the attempt of societies to reflect on and act upon their increasing differentiation and the development of the state with all its emerging functions, there is something peculiar to the self-reflection that led to IR as a discipline. Here, it is not with the distant view of science that social and political 
practice is improved; it is rather the other way round: it is through recourse to the lessons of practice that science is constituted." (Guzzini, 2013, p. 524)

Berpijak pada penelusuran yang dilakukan oleh Norbert Elias atas bagaimana ranah dan habitus dari "Court Aristocracy" Perancis menjadi landasarn bagi identitas diplomasi Eropa, keberadaan mereka sebagai komunitas, cara mereka melihat dan melakukan sesuatu, dan pengetahuan praktis mereka yang tersebar, Guzzini menekankan pada proses di mana habitus inilah yang kemudian terlembagakan menjadi apa yang kita kenal hari ini sebagai "budaya diplomatik" yang terus-menerus direproduksi khususnya dalam wujud budaya negosisasi di antara aktor internasional (Guzzini, 2013, pp. 525-526). "Court Aristokrasi” adalah pembawa bagi norma perilaku tertentu (habitus) yang paling kuat bertahan selama ini dan dimanamana, terutama dalam bidang diplomatik dan urusan luar negeri. Ketika perubahan politik membawa kelas menengah ke dalam posisi ini pada awal abad ke-20, mereka tidaklah membawa norma mereka untuk menggantikan habitus pra-revolusi ini, melainkan justru mengadopsi dan mereproduksinya di dalam ranah diplomatik dan urusan luar negeri, yang memang mereka (kelas menengah) tidak memiliki pengalaman spesifik di bidang ini (Guzzini, 2013, p. 424).

Ketika perubahan di dalam masyarakat mendorong pengembangan ilmu pengetahuan menjadi sangat dibutuhkan, baik bagi pengetahuan itu sendiri, bagi kontrol ataupun legitimasi penguasa, kehadiran disiplin HI yang muncul belakangan, dalam bingkai analisis ini menjadi penting sebagai jalan untuk meyakinkan masyarakat diplomatik dunia baru yang lebih luas, mengenai, sekaligus melestarikan, pengetahuan praktis yang telah ada dalam bidang diplomatik dan militer, yang berakar pada habitus spesifik elit aristokrat sebelumnya (Guzzini, 2013, p. 524). Dengan kata lain dalam penelusuran sejarah ini, studi HI sebagai disiplin ilmu tidaklah lahir untuk mengubah tradisi, melainkan sebaliknya justru lebih

Tabel 2 Peta Teorisasi HI - Jackson \& Nexon

\begin{tabular}{|c|c|c|c|c|}
\hline \multirow[b]{2}{*}{ Kelompok Teori HI } & \multicolumn{4}{|c|}{ POSISI YANG SALING TERKAIT } \\
\hline & Pendekatan Teoritis & Konteks & Aktor & $\begin{array}{l}\text { Generalisasi \& } \\
\text { Abstraksi }\end{array}$ \\
\hline Choice-theoretic & $\begin{array}{l}\text { Menetapkan jumlah } \\
\text { aktor yang terbatas, } \\
\text { mencakup disposisi, } \\
\text { dan logika } \\
\text { pengambilan } \\
\text { keputusan yang } \\
\text { berlaku pada } \\
\text { masing-masing } \\
\text { aktor }\end{array}$ & $\begin{array}{l}\text { Membentuk } \\
\text { disposisi, misalnya } \\
\text { pilihan dan norma; } \\
\text { menentukan aktor- } \\
\text { aktor yang relevan }\end{array}$ & $\begin{array}{l}\text { Diperlakukan } \\
\text { sebagai pengambil } \\
\text { kebijakan otonom } \\
\text { pada momen } \\
\text { interaksi }\end{array}$ & $\begin{array}{l}\text { Model dapat } \\
\text { berubah dalam } \\
\text { konteks yang } \\
\text { beragam }\end{array}$ \\
\hline Experience-near & $\begin{array}{l}\text { Menemukan } \\
\text { kembali dunia } \\
\text { kehidupan dari aktor } \\
\text { tertentu atau } \\
\text { kelompok aktor }\end{array}$ & $\begin{array}{l}\text { Menyusun objek } \\
\text { utama dari analisis } \\
\text { guna memahami } \\
\text { tindakan sosial }\end{array}$ & $\begin{array}{l}\text { Bersifat sangat } \\
\text { mengakar; tidak ada } \\
\text { status analisis yang } \\
\text { benar-benar bebas } \\
\text { dari konteks }\end{array}$ & $\begin{array}{l}\text { Variasi di dalam } \\
\text { karakteristik } \\
\text { kontekstual } \\
\text { membatasi } \\
\text { ekstrapolasi }\end{array}$ \\
\hline Social-relational & $\begin{array}{l}\text { Menganalisis relasi } \\
\text { dan posisi aktor } \\
\text { dalam suatu latar } \\
\text { sosial yang lebih } \\
\text { luas }\end{array}$ & $\begin{array}{l}\text { Menstrukturkan } \\
\text { tindakan sosial }\end{array}$ & $\begin{array}{l}\text { Sangat mengakar; } \\
\text { atribut, kapasitas } \\
\text { utama dari aktor, } \\
\text { dll. berakar dari } \\
\text { relasi }\end{array}$ & $\begin{array}{l}\text { Dapat membawa } \\
\text { implikasi perubahan } \\
\text { dalam relasi dan } \\
\text { posisi, juga unsur } \\
\text { dari keseluruhan } \\
\text { konteks }\end{array}$ \\
\hline
\end{tabular}


sebagai tradisi yang dimapankan ke dalam ilmu pengetahuan (Guzzini, 2013, p. 524). Disiplin HI tidaklah lahir untuk memproduksi pengetahuan tentang dunia, melainkan pengetahuan tentang dunia yang telah ada yang justru memproduksi disiplin HI sebagai bidang ilmu pengetahuan.

Berpijak pada analisis ini, dengan demikian dapat dikonstruksikan ulang penulisan sejarah perkembangan teori HI, yang menjadi posisi dasar dalam artikel ini, dalam wujud kisah yang berbeda. Bukan dalam wujud pengulangan kisah perkembangan yang berjalan melalui perdebatan, melainkan kisah tentang perkembangan teorisasi $\mathrm{HI}$ yang diwarnai oleh pertarungan di antara upaya untuk mendisiplinkan pengetahuan tentang dunia melalui studi $\mathrm{HI}$ dengan upaya untuk menciptakan disiplin yang dapat menghasilkan pengetahuan tentang dunia dengan segenap dinamika dan perkembangannya.Perkembangan teori $\mathrm{HI}$ dengan demikian, merefleksikan pertarungan ini, bahkan sampai dengan hari ini. Di satu sisi, tetap bertahan upaya-upaya untuk mendisiplinkan studi HIyang secara terus-menerus melembagakan, menormalkan dan mereproduksi pengetahuan dan praktik yang selama ini telah ada yang dianggap niscaya dan alamiah.

Manifestasinya, terwujud dalam teorisasi-teorisasi yang bersifat state-centric, policy-oriented, problem-solving theory, yang dilandasi oleh semangat disiplin-sentris, yang secara berkelanjutan menciptakan dikotomi HI dan bukan-HI. Di sisi lain, bergeliat upaya teorisasi yang berupaya untuk menjawab permasalahan dunia dengan semangat yang terbuka dan menembus sekat-sekat kedisiplinan, yang mengganggu stabilitas dan praktik serta pengetahuan yang selama ini telah dianggap normal dan mapan di dalam studi ini. Berbagai bentuk peralihan-peralihan yang menandai perkembangan teori HI selama ini, mulai dari peralihan normatif sampai kepada peralihan estetik adalah perwujudan nyata dari semangat ini.

BERSEMINYA BUNGA-BUNGA TEORI: MASALAH LONCATAN FILOSOFIS DAN PENJARA TEKNIS

Di tengah kisah duka tentang kematian teori HI, narasi lain muncul dalam upaya untuk memetakan situasi dan status dari teori HI kontemporer. Seiring dengan semakin redupnya cahaya perdebatan dalam perkembangan studi HI, beberapa penstudi justru melihat beberapa titik cahaya terang dalam wujud proliferasi teori HI yang berkembang sejak tahun 1990an.Berseminya bunga-bunga teori, merupakan sebuah fakta yang tidak dapat dipungkiri, bahwa selama hampir satu abad keberadaan studi HI, terdapat jauh lebih banyak orientasi teoritis yang berlaku di dalam HI hari ini ketimbang dekade awal kemunculannya (Dunne, 2013). Geliat kemunculan teori-teori yang sebagian besar berada dalam ranah middle-level/middle-range theory ini, menjadi sebuah narasi tersendiri, sebuah kisah alternatif, mengenai perkembangan teori HI yang keluar dari bingkai "perdebatan."

Teori dalam makna ini merupakan cerita dalam memahami korelasi, sebagian diantaranya mewujud pada teori-teori yang mengacu kepada model-model game-theoretic, juga dalam wujud "analytic narratives" yang dikedepankan oleh penstudi dalam kerangka pilihan rasional (rational-choice) (Robert H. Bates, 1998), beberapa fokus mengenai logika sosial dari tindakan individu (Olsen, 1998), atau yang fokus pada serangkaian proses dalam wujud "path dependence" dan "sequencing." (Jackson, 2013, p. 548) Secara keseluruhan, gambaran mengenai teorisasi pada level tengah ini bersifat sangat beragam dan tumpang-tindih. Perkembangan teorisasi dalam bingkai ini berjalan dalam corak yang sangat beragam. Sulit untuk memetakan afiliasi "isme" dari perkembangan teoriteori mid-level ini. Pluralisme metodologis pun mewarnai proliferasi ini, membentang dari sejarah, studi kasus, sampai kepada statistik dan matematika.Perkembangan teorisasi ini pun tampak menabrak pakem tingkatan analisis yang selama ini menjadi standar dalam studi HI. Asumsi yang beragam tampak diaplikasikan dalam teorisasi atas isu-isu yang spesifik bahkan terbatas dalam periode historis tertentu (Lake, 2013). Eklektikisme merupakan corak dari proliferasi teori HI pasca meredupnya narasi tentang perdebatan yang selama ini mendominasi 
penulisan sejarah studi ini. Teorisasi pada ranah midrange ini tampak menyusun mayoritas studi empiris yang muncul di jurnal-jurnal papan atas Amerika, seperti International Organization, American Political Science Review, dan International Studies Quarterly (Jackson, 2013, p. 548).

Terdapat tiga pendorong utama yang berada di balik berseminya bunga-bunga teori, terutama yang berkembang dalam katagori mid-range theory ini. Pertama, penemuan teori-teori baru yang dilandasi oleh pandangan umum sebagian komunitas akademis yang meyakini bahwa suatu konteks historis baru memerlukan alat-alat analisis konseptual yang baru (Dunne, 2013, p. 412). Kedua, praktik-praktik mengimpor teori dari disiplin-disiplin lain yang memiliki kesamaan. ${ }^{4}$ Ketiga, proliferasi teoritis ini juga didorong oleh perkembangan yang terjadi di dalam disiplin HI itu sendiri (Dunne, 2013, p. 413).

Meskipun hadir sebagai wujud narasi alternatif atas penulisan sejarah perkembangan teori $\mathrm{HI}$, geliat perkembangkan teori yang dikisahkan dalam narasi ini mengandung permasalahan tersendiri. Pertama, keberagaman teori merupakan sebuah tanda yang positif bagi perkembangan suatu bidang ilmu, bahkan merupakan bagian integral dari ilmu pengetahuan itu sendiri (Dunne, 2013, p. 415). Akan tetapi, berseminya bunga-bunga teori HI pasca "perdebatan" justru menunjukkan gejala yang tidak lagi bergerak dalam bingkai keberagaman, melainkan lebih kepada kegaduhan dan hiruk-pikuk teorisasiyang berjalinkelindan dengan kompleksitas dan ketidakpastian permasalahan dalam dunia kontemporer (Jackson, 2013, p. 543). Ketika teorisasi berkembang cepat dan pesat dalam rangka menghadirkan jawaban atas kompleksitas permasalahan dunia kontemporer, sebuah permasalahan mendasar muncul dalam bentuk semakin pudarnya kejelasan dan kesadaran secara eksplisit mengenai jalur dan prosedur menuju produksi pengetahuan di dalam bingkai disiplin studi HI itu sendiri. Loncatan filosofis adalah corak yang paling kental mewarnai proliferasi teori-teori $\mathrm{HI}$ kontemporer. Karakter teorisasi HI semakin diwarnai oleh hiruk-pikuk dan kesibukan para penstudinya atas urusan yang menjadi perhatiannya sendiri, di mana penelitian dijalankan tanpa lagi didasari oleh kesadaran akan jalur dan prosedur yang justru mendasari asumsi dan bahasa teori itu sendiri. Tidak tampak lagi upaya yang ditekankan untuk mempertahankan dan mengklarifikasi fondasi filosofis yang melandasi proses teorisasi. Teori tampak menjadi "alat siap pakai" yang langsung dihadirkan untuk menjawab permasalahan, tanpa didasari oleh asumsi dan prosedur yang mendasari teori tersebut. Fondasi filosofis menjadi semakin pudar di tengah berseminya bunga-bunga teori. Sementara, fondasi filosofis, yang dengan jelas menjadi dasar klarisikasi atas posisi ontologis, epistemologis, dan metodologis dari teori, merupakan bagian yang paling mendasar dalam kerja dari pengetahuan sebagai upaya sistematis untuk memproduksi pengetahuan. Tanpa klarifikasi atas fondasi filosofis ini, sulit untuk mengukur dan memastikan bahwa sebuah penelitian telah dijalankan di dalam suatu jalur dan prosedur yang jelas. Fred Chernoff menegaskan empat peranan penting dari filsafat ilmu sebagai landasan dalam teorisasi: (1) filsafat ilmu menjadi landasan dalam memperlihatkan kekuatan dari sebuah argumentasi HI dibandingkan dengan yang lain; (2) memperlihatkan perbedaan di antara "fondasi pendukung" dan "fondasi teori-teori pengetahuan"; (3) sebagai strategi retoris dalam mengedepankan sebuah posisi dalam perdebatan akademis; (4) mengklarifikasi landasan rasional dalam menentukan titik awal penelitian (Chernoff, 2013).

Kedua, proliferasi teori yang berkembang selama beberapa tahun terakhir di dalam studi HI ini justru muncul dalam geliat normalisasi pendekatan positivis, dengan serangkaian prosedur teknis yang siap pakai dan diposisikan sebagaiprosedur umum dalam penelitian HI atau bahkan satu-satunya prosedur dalam penelitian HI. Yang menjadi permasalahan di sini, bukanlah pada pendekatan positivisme-nya, melainkan gestur proliferasi teori $\mathrm{HI}$ yang tidak hanya didominasi oleh pendekatan ini, namun yang meletakkan pendekatan ini sebagai landasan bagi prosedur penelitian "yang baik."Sebuah konsekuensi 
dari gejala ini sangatlah serius bagi arah teorisasi HI kontemporer, di mana tanpa disadari, proliferasi ini justru mengarah kepada munculnya kembali imperialisme metodologis yang menibastkan satu pendekatan sebagai satu-satunya yang saintifik. Sekali lagi, permasalahannya bukan pada pendekatan positivis-nya, melainkan kembali lagi kepada permasalahan pertama, geliat perkembangan dan dominasi dari positivisme di dalam teorisasi HI selama ini justru tidak dilandasi oleh keakuratan pemahaman dan klarifikasi prosedur dari positivisme itu sendiri. Sebagaimana yang ditelusuri oleh Patrick T. Jackson, positivisme di dalam HI pada dasarnya tidak memadai untuk dikategorikan sebagai jalur positivis dalam filsafat ilmu, di mana permasahan mendasarnya terletak pada ketidakjelasan prosedur dan jalur menuju pengetahuan yang digunakan dalam teorisasi HI ketika dibenturkan dengan trajektori positivisme di dalam filsafat ilmu, mulai dari Descartes sampai kepada Imre Lakatos (Jackson, The Conduct of Inquiry in International Relations: Philosophy of science and its implications for the study of world politics, 2011).

Ketiga, proliferasi teorisasi $\mathrm{HI}$ ini juga diwarnai oleh geliat teknis dari penelitian HI yang didesak oleh dinamika permasalahan dunia kontemporer dan tradisi pengajaran di universitas. Permasalahan ini terwujud dalam kecenderungan pengajaran teknis aplikasi teori dan alat analisis instan, "siap pakai" bagi mahasiswa untuk dapat dengan cepat menyelesaikan proyek penelitian mereka (Walt, 2013). Selain menjadi hambatan tersendiri bagi perkembangan teorisasi $\mathrm{HI}$, gejala ini lagi-lagi membuka kembali ruang bagiimperialisme pendekatan yang dinisbatkan sebagai yang telah normal dan terlembaga di dalam disiplin pengetahuan.

\section{TAWARAN DAN PERTARUHAN}

Menyimak kembali permasalahan yang dibawa oleh historiografimainstream "perdebatan" atas perkembangan teori $\mathrm{HI}$, di satu sisi tampak bahwa semakin redupnya fitur-fitur dari narasi ini dalam studi HI selama beberapa tahun terakhir sebagai indikasi positif bagi masa depan perkembang teori.Terlebih dengan mencuatnya dinamika baru dalam wujud proliferasi yang menyemarakkan geliat teorisasi dalam menjawab permasalahan dunia kontemporer dengan corak yang semakin kompleks dan tidak pasti. Akan tetapi, di sisi lain, di dalam kisah tentang berseminya bunga-bunga teori ini justru melekat permasalahannya tersendiri yang justru dapat membawa upaya produksi pengetahuan tentang dunia melalui disiplin $\mathrm{HI}$ itu sendiri kembali kepada permasalahan klasik dalam bentuk pendisiplinan pengetahuan tentang dunia.

Membangkitkan kembali fondasi filosofis dan mendorong semangat serta prinsip pluralisme menjadi tawaran positif yang muncul dari beberapa penstudi HI kontemporer, mulai dari Patrick Jackson, Tim Dunne, Andrew Benett sampai kepada Fred Chernoff. Sebagaimana telah dijelaskan sebelumnya, membangkitkan kembali kesadaran akan fondasi filosofis memainkan peranan yang sangat penting dalam menjawab permasalahan ini. Hiruk-pikuk, kegaduhan proliferasi teori dapat ditarik kembali ke dalam bingkai keberagaman, di mana penelitian dijalankan dengan berlandaskan pada kesadaran akan posisi ontologis, epistemologis dan metodologis yang menyediakan jalur dan prosedur yang dapat diperiksa dengan jelas dalam upaya untuk memproduksi pengetahuan tentang dunia. Hasrat imperialis metodologis pun dapat diatasi dengan kesadaran akan fondasi filosofis dan pluralisme metodologis, di mana komunikasi keilmuan tidak dalam rangka mengibarkan bendera kemenangan dari satu pendekatan, melainkan dalam wujud pemeriksaan internal dan lintas metodologi dalam prosedur penelitian.

Terlebih jika dicermati dari tawaran pluralisme yang muncul mulai dari Jackson, Dunne, Hansen, Wight, Benett, sampai ke Chernoff, bukanlah bentuk pluralisme yang tertutup, di mana penstudi HI memenjarakan diri masing-masing dalam jalur dan prosedur penelitiannya sendiri-sendiri, tanpa berkomunikasi satu sama lain. Semangat pluralisme yang muncul sejauh ini, lebih kepada pluralisme yang tetap membuka diri terhadap komunikasi, terhadap ketidaksepakatan, perbedaan, dan tujuan untuk memproduksi pengetahuan tentang dunia dengan jalur 


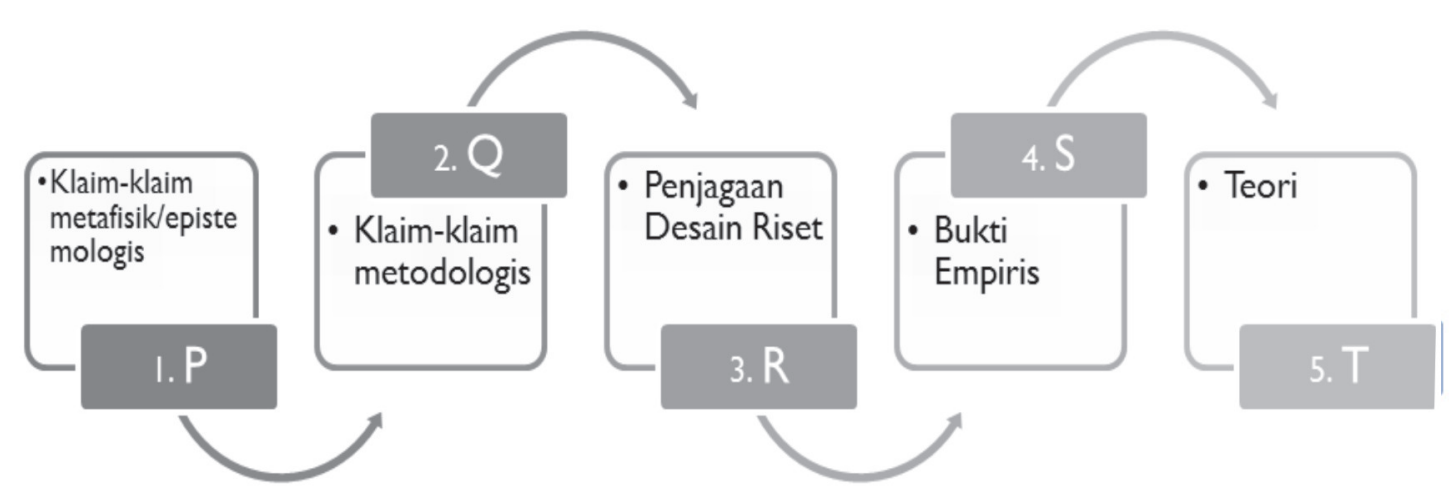

Gambar 1: Skema Ó Teorisasi HI - Fred Chernoff

pengetahuan dan prosedur yang selalu terbuka bagi perkembangan yang dinilai lebih baik. Komitmen dan kesadaran filosofis di sini bukanlah mewujud ke dalam bentuk keyakinan teologis yang harus diukur dengan kesetiaan pada satu bentuk posisi. Melainkan kesetiaan kepada upaya terus-menerus untuk menghasilkan pengetahuan dengan jalur dan prosedur yang dapat diklarifikasi dan diperbaiki.

Sebagai sebuah respon dan klarifikasi atas komitmen filosofis dan pluralisme yang ditawarkan Patrick T. Jackson, Fred Chernoff merumuskan suatu bentuk skema teorisasi HI, sebagaimana tercantum di Gambar 1:

Melalui skema ini, filsafat ilmu dapat memainkan peranan penting dalam proses teorisasi hubungan internasional, di mana terkandung baik secara eksplisit maupun implisit landasan yang paling mendasar sampai kepada prosedur teknis dalam produksi teori HI. Berlandaskan pada skema ini, permasalahan pluralisme juga dapat diatasi, di mana tersedia tahapan teorisasi yang jelas untuk dapat melandasi dialog, komunikasi keilmuan tanpa hasrat imperialis.Skema ini juga menjadi landasan bagi pengembangan teorisasi HI yang tidak hanya berbasis pada pluralisme, tetapi juga kompleksitas, di mana tercipta ruang-ruang untuk melakukan penilaian silang antar proyek produksi pengetahuan, dalam rangka menghasilkan teori-teori yang benar-benar dapat secara obyektif menjelaskan dinamika dunia kontemporer yang memang semakin kompleks dan tidak pasti.
Akan tetapi, sebelum menyambut tawaran ini sebagai bingkai bagi perkembangan teorisasi HI kontemporer, sebuah permasalahan lain harus diklarifikasi terlebih dahulu, khususnya mengenai apa yang menjadi pertaruhan dari upaya untuk mendorong perkembangan teorisasi HI itu sendiri.Secara umum, tampak sebuah hasratdari upaya untuk membingkai secara sistematis perkembangan teorisasi meletakkan progress dari disiplin ilmu HI sebagai pertaruhan yang paling utama, di mana bingkai teorisasi ini dapat melandasi terciptanya disiplin HI yang dapat menghasilkan teori-teori spesifik tentang dunia. Menyelamatkan eksistensi disiplin ilmu HI secara lugas merupakan manifestasi dari pertaruhan ini, di tengah kekaburan sekat-sekat disiplin yang menjadi pembatas bagi mana yang HI dan bukan HI.Hadir permasalahan tersendiri dari wujud pertaruhan ini, di mana eksistensi disiplin secara sistematis ditegakkan melalui pendisiplinan pengetahuan tentang dunia. Lagi-lagi, terbuka peluang bagi disiplin HI untuk ditarik kembali ke dalam tradisi lama, di mana pengetahuan dan praktik yang telah ada dilembagakan dan dinormalisasikan ke dalam disiplin ilmu pengetahuan. Sehingga, HI sebagai disiplin ilmu akan berkembang dalam kotak-kotak yang telah disediakan, tanpa dapat keluar bahkan berkomunikasi dengan disiplin lain. HI sebagai disiplin ilmu dengan segenap teorisasinya, dengan demikian tidak dapat diharapkan mampu menghadirkan pengetahuan tentang dunia kontemporer yang semakin kompleks dan tidak pasti, 
sedari trayektori terbalik proses penciptaan pengetahuan berbasis ilmu tetap mendapatkan tempat di dalamnya.

\section{KESIMPULAN}

Sebuah wujud pertaruhan kedua tampak memberikan harapan yang lebih mencerahkan bagi disiplin ilmu HI, di mana pembingkaian sistematis teorisasi HI kontemporer diarahkan untuk menciptakan sebuah disiplin di mana pengetahuan yang dapat menjawab ragam permasalahan kompleks dan tidak pasti dari dinamika dunia kontemporer dapat dihasilkan. Sebuah trayektori ideal di mana ilmu pengetahuan lahir sebagai wujud dari upaya untuk menghasilkan pengetahuan tentang dunia yang terus berubah, dapat didorong melalui hasrat ini. Teorisasi yang bersifat problem-based merupakan corak utama dari penelitian dalam geliat yang berbasis pada hasrat ini. Kemampuan teori-teori HI dalam menjawab permasalahan dan menjelaskan perubahan dan dinamika dunia kontemporer adalah wujud pertaruhan utama, jika perkembangan teorisasi HI tidak dibingkai dalam upaya teorisasi yang sistematis dengan prosedur yang dapat diklarifikasi.

Upaya teorisasi HI yang berlandaskan dan berawal dari masalah yang spesifik dalam kontemporalitas dunia adalah tawaran utama dalam artikel ini. Akan tetapi, meletakkan permasalahan sebagai pijakan awal dari teorisasi dapat melahirkan permasalahan baru yang justru berujung kembali kepada kegaduhan dan hiruk-pikuk proliferasi teori-teori HI, sedari masalah dapat muncul dari pijakan yang berbeda-beda, mulai dari dinamika dunia kontemporer sendiri yang sangat kompleks, penuh dengan ketidakpastian dan persilangan serta keterhubungan di antara ragam dimensi, sampai kepada pijakan epistemologis dan metodologis yang juga membingkai cara dari para penstudinya dalam melihat dan memaknai apa yang dipandang sebagai masalah.

Untuk mengatasi masalah ini, mengangkat kembali prinsip mengenai "keberpihakan" merupakan sebuah tawaran yang diajukan. Jika teorisasi HI kontemporer dibingkai dalam upaya untuk menyelesaikan masalah, pertanyaan yang paling mendasarnya adalah "masalah apa dan masalahnya siapa?" Apakah masalah sistem? Masalah negara? Masalah bangsa? Masalah masyarakat? Masalah kelas? Masalah individu? Yang dapat dilanjutkan dengan masalah sistem, negara, bangsa, masyarakat, kelas, atau individu yang mana? Ataukah masalah mayoritas hidup umat manusia yang hari ini dibingkai, direkayasa, diproduksi dan direproduksi oleh tatanan kapitalisme kontemporer? Sederet pertanyaan ini, mensyaratkan bahwa sedari pijakan masalah pun harus didudukkan pada pemahaman yang mendasar tentang bagaimana corak dan dinamika masalah yang muncul dalam dunia kontemporer. Dari titik inilah posisi dan keberpihakan diletakkan untuk mengawali teorisasi HI yang bersifat problem-based. Tentu saja, prinsip problem-based di sini tidak dapat direduksi ke dalam kategori teorisasi problem-solving yang menyasar masalah-masalah teknis dan residual di dalam tatanan dunia, sedari kesadaran filosofis dan keberpihakan menjadi bingkai utamanya. Pada akhirnya, skema Ó yang ditawarkan Chernoff sebagai bingkai teorisasi $\mathrm{HI}$ di atas harus diawali dengan identifikasi dan pengajuan masalah yang berbasis keberpihakan. Sehingga, geliat teorisasi HI dapat bergerak menuju arah yang membebaskan diri dari modus kuasa yang mengawali proses awal kelahirannya, yang justru sebagai disiplin ilmu yang diabdikan untuk menyelesaikan segelintir masalahelit-elit partikular dan menopang bekerja dan lestarinya suatu tata dunia yang mengontrol hidup dan menghadirkan masalah bagi mayoritas umat manusia di dunia

\section{CATATAN AKHIR}

David A. Lake melakukan interpretasi ulang atas perdebatan ini dengan mencermati celah-celah di dalam setiap episode yang tidak pernah diceritakan dalam narasi tentang Perdebatan Besar tersebut. Lihat juga Tim Dunne, Michael Cox \& Ken Booth, eds. The Eighty Years' Crisis: International Relations, 1919-1999 (New York: Cambridge University Press, 1998); B.C. Schmidt, "On the history and historiography of International Relations," dalam Walter E. Carlsnaes, Thomas Risse, \& Beth A. Simmons, eds. Handbook of International Relations (Thousand Oaks: Sage, 2013), 3-28.

2 Sebuah manifestasi dari analisis khas reflektivis yang tidak memisahkan antara teori dan praktik. Stefano Guzzini, "The ends of International Relations theory," 534.

3 Teori HI sebagai ontologi saintifik menurut Jackson dan Nexon 
menekankan pada: aktor yang menyusun politik dunia; konteks dan lingkungan dari aktor tersebut; arti penting relative dari konteks dan lingkungan tersebut dalam memahami dan menjelaskan fenomena internasional; penjelasan mengenai bagaimana kesemua terhubung; proses yang menyusun lokus utama analisis; kesalingterhubungan di antara proses-proses tersebut. Patrick Thaddeus Jackson \& Daniel H. Nexon, "International theory in a post-paradigmatic era," 550-551.

4 Praktik impor teori dari disiplin lain ini adalah sebuah corak utama dari interdisiplinaritas studi HI itu sendiri. Sebagai contoh misalnya, teorisasi politik luar negeri sebagai permainan bahasa yang dilakukan oleh Karin Fierke berpijak pada pemikiran Wittgenstein, lihat Karin Fierke, "Multiple identities, interfacing games: The social construction of Western action in Bosnia," European Journal of International Relations 2 (1996): 467-497 dan Karin Fierke, Political Selfsacrifice: Agency, Body and Emotion in International Relations (Cambridge and New York: Cambridge University Press, 2013); Teori sekuritisasi yang dikembangkan oleh Ole Waever sangat dipengaruhi speech act theory ala John Langshaw Austin, lihat Ole Waever, "Securitization and desecuritization," dalam R.D. Lipschutz, ed. On Security (NewYork: Colombia University Press, 1995): 46-86; Begitu juga dengan konstruktivisme Alexander Wendt yang banyak dipengaruhi oleh Anthony Giddens dan Roy Bashkar. Secara keseluruhan, lihat, Tim Dunne, Lene Hansen \& Colin Wight, "The end of International Relations theory?" 413.

\section{REFERENSI}

Bates, Robert H., A. Greif, J.L. Rosenthal, et.al. eds. Analytic Narratives (Princeton: Princeton University Press, 1998).

Bennett, Andrew. "The mother of all isms: Causal mechanisms and structured pluralism in International Relations Theory." European Journal of International Relations 19(3) (2013): 459-481.

Brown, Chris. "The Poverty of Grand Theory," European Journal of International Relations 19(3) (2013): 583-497.

Chernoff, Fred. "Science, Progress and Pluralism in the Study of International Relations." Millennium: Journal of International Studies 41(2) (2013): 346-366.

Dunne, Tim, Michael Cox \& Ken Booth, eds. The Eighty Years' Crisis: International Relations, 1919-1999 (New York: Cambridge University Press, 1998).

Dunne, Tim. Lene Hansen \& Colin Wight, "The end of International Relations theory?" European Journal of International Relations 19(3) (2013): 405-425.

Fierke, Karin. "Multiple identities, interfacing games: The social construction of Western action in Bosnia," European Journal of International Relations 2 (1996): 467-497.

Fierke, Karin. Political Self-sacrifice: Agency, Body and Emotion in International Relations (Cambridge and New York: Cambridge University Press, 2013).

Guzzini, Stefano. "The ends of International Relations theory: Stages of reflexivity and modes of theorizing," European Journal of International Relations 19(3) (2013): 521-541.

Jackson, Patrick Thaddeus \& Daniel H. Nexon. "Paradigmatic faults in International-Relations Theory," International Studies Quarterly 53(4) (2009): 907-940.
Jackson, Patrick Thaddeus. The Conduct of Inquiry in International Relations: Philosophy of science and its implications for the study of world politics. (London \& New York: Routledge, 2011).

Jackson, Patrick Thaddeus \& Daniel H. Nexon. "International theory in a post-paradigmatic era: From substantive wagers to scientific ontologies." European Journal of International Relations 19(3) (2013): 543-565.

Kuhn, Thomas. The Structure of Scientific Revolutions (Chicago: University of Chicago Press, 1962).

Lakatos, Imre. "Falsification and the methodology of scientific research programmes," dalam Imre Lakatos \& Alan Musgrave, eds. Criticism and the Growth of Knowledge (Cambridge: Cambridge University Press, 1970).

Lake, David A. "Theory is dead, long live theory: The end of the Great Debates and the rise of eclecticism in International Relations." European Journal of International Relations 19(3) (2013): 567-587.

Maliniak, Daniel, Oakes A., \& Susan Peterson. TRIP Around the World: Teaching, Research, and Policy Views of International Relations Faculty in 20 Countries (Williamsburg, VA: College of William and Mary, 2007).

March, J.G. \& J.P. Olsen. "The institutional dynamics of international political orders." International Organization 52(3) (1998): 943-969.

Mearsheimer, John J. \& Stephen M. Walt, "Leaving theory behind: Why simplistic hypothesis testing is bad for International Relations," European Journal of International Relations 19(3) (2013): 427-457.

Schmidt, B.C. "On the history and historiography of International Relations," dalam Walter E. Carlsnaes, Thomas Risse, \& Beth A. Simmons, eds. Handbook of International Relations (Thousand Oaks: Sage, 2013).

Sterling-Folker, Jennifer. Theories of International Cooperation and the Primacy of Anarchy: Explaining US International Monetary PolicyMaking after Bretton Woods (Albany: State University of New York Press, 2002).

Waever, Ole. "Securitization and desecuritization," dalam R.D. Lipschutz, ed. On Security (New York: Colombia University Press, 1995).

Wight, Collin. "Incommensurability and cross-paradigm communication in International Relations Theory: 'What's the frequency of Kenneth?" Millennium: Journal of International Studies 25(2) (1996): 291-319. 